\title{
Review of the Diagnostic Evaluation of Normal Anion Gap Metabolic Acidosis
}

\author{
Kenrick Berend \\ St. Elisabeth Hospital, Willemstad, Curaçao
}

\section{Keywords}

Acidosis · Anion gap · Hyperchloremia - Osmolal gap · Renal-tubular acidosis · Urine $\mathrm{pH}$

\section{Abstract \\ Background: Normal anion gap metabolic acidosis is a com- mon but often misdiagnosed clinical condition associated with diarrhea and renal tubular acidosis (RTA). Early iden- tification of RTA remains challenging for inexperienced phy- sicians, and diagnosis and treatment are often delayed. Summary: The presence of RTA should be considered in any patient with a high chloride level when the $\mathrm{CL}^{-} / \mathrm{Na}^{+}$ratio is above 0.79 , if the patient does not have diarrhea. In patients with significant hyperkalemia one should evaluate for RTA type 4, especially in diabetic patients, with a relatively con- served renal function. A still growing list of medications can produce RTA. Key Messages: This review highlights practical aspects concerning normal anion gap metabolic acidosis.}

(c) 2017 S. Karger AG, Basel

This review was presented at the 2nd International Acid-Base, Electrolyte Network Gathering and the International Society of Nephrology Continuing Medical Education (ISN CME) in January 12-14, 2017, in China.

\section{KARGER}

(C) 2017 S. Karger AG, Basel

E-Mail karger@karger.com

www.karger.com/kdd

\section{Introduction}

For more than 40 years, clinicians have used the anion gap $(A G)$ as a major tool to evaluate acid-base disorders [1-5]. An increased value of the AG suggests a possible organic acidosis due to endogenous acids or exposure to exogenous acids [1]. Although the concept of the AG was described in 1936 by James Gamble [6], it did not gain widespread recognition by physicians until the 1970s after the introduction of autoanalyzers and the rapid availability of multiple analytes [3]. According to Gamble [6], electrical neutrality in solution demands that the sum of the cations is equal to the sum of the anions, also represented in a gamblegram (Fig. 1). Sodium, chloride, bicarbonate, and albumin are quantitatively the major ions in the extracellular fluid compartment and are therefore used to calculate the AG. A true "ion gap," however, does not exist in vivo which makes the AG a fundamental tool to evaluate acid-base disorders [1]. From Figure 1 it is obvious that the elements used in the AG equation are quantitatively the most prominent electrolytes in plasma:

$$
\left[\mathrm{Na}^{+}\right]-\left[\mathrm{Cl}^{-}\right]-\left[\mathrm{HCO}_{3}^{-}\right] \text {. }
$$

\section{Reference Ranges of the AG}

Many reference ranges of the $A G$ have been reported from about 5 to $14 \mathrm{mEq} / \mathrm{L}$, with autoanalyzers using an ion-selective electrode. However, the AG value is depen-

Kenrick Berend, PhD, MD

St. Elisabeth Hospital

Breedestraat 193

Willemstad (Curaçao)

E-Mail kenber2@me.com 


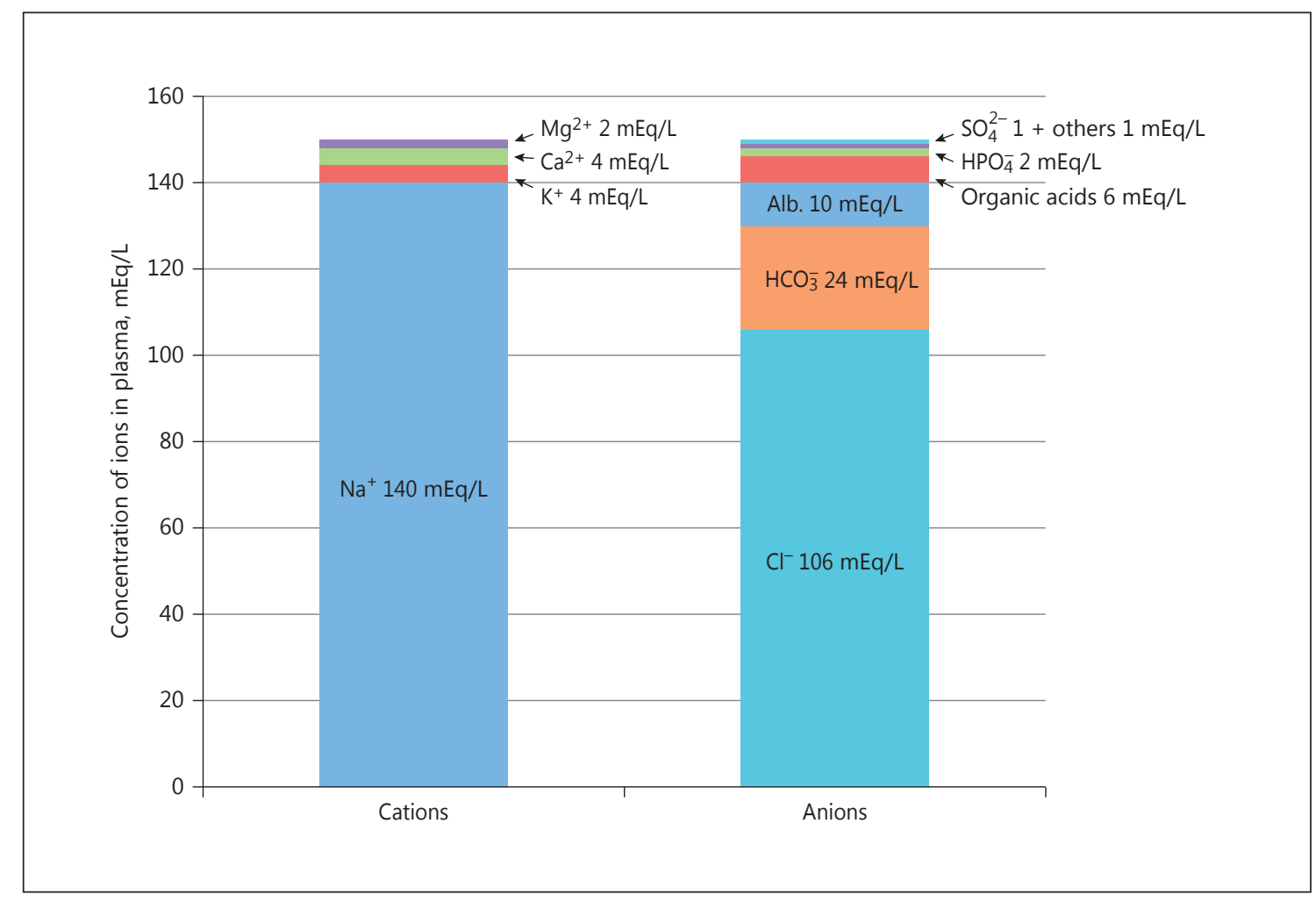

Fig. 1. Gamblegram: balance between anions and cations in plasma.

dent on the type of instrument used to measure its components. In the study reported by Roberts et al. [3], the AG value was $5-10 \mathrm{mEq} / \mathrm{L}$ with the Synchron CX3 analyzer (Beckman Coulter), 9-14 mEq/L for the Hitachi 717 analyzer (Boehringer Mannheim, Mannheim, Germany), and $8-13 \mathrm{mEq} / \mathrm{L}$ for the Vitros 950 analyzer (Johnson \& Johnson, New Brunswick, NJ, USA). In another study in 4,525 healthy adults, AG varied from 8.5 to $15.2 \mathrm{mEq} / \mathrm{L}$, with a mean value of $11.6 \mathrm{mEq} / \mathrm{L}$ [5]. Therefore, one should know the reference range of the analyzer used and, if known, the patient's baseline AG, too. One should also realize that reference ranges are usually based upon venous bicarbonate values that may be about $1-2 \mathrm{mEq} / \mathrm{L}$ higher than arterial values [7]. Changes in sodium concentration are dependent on the water content of plasma and go hand in hand with the chloride concentration, and, therefore, AG evaluation remains a useful tool in dysnatremia.

Serum AG is affected by the concentrations of all anions and cations which are not included in its calculations: i.e., albumin, globulin, potassium, calcium, magnesium, and organic and inorganic acids. Because of the narrow extracellular concentration, most ions are omitted from the calculation. Nevertheless, one should correct the AG for hypoalbuminemia. To appreciate the relevance of this correction, one can consider a healthy individual with the following serum values: $\left[\mathrm{Na}^{+}\right]=$ $140 \mathrm{mEq} / \mathrm{L},\left[\mathrm{Cl}^{-}\right]=106 \mathrm{mEq} / \mathrm{L},\left[\mathrm{HCO}_{3}^{-}\right]=24 \mathrm{mEq} / \mathrm{L}$. The $\mathrm{AG}=10 \mathrm{mEq} / \mathrm{L}$, representing primarily albumin. The correction factor for albumin is $2.3-2.5 \times$ [albumin], in $\mathrm{g} / \mathrm{dL}$ [1]. Therefore, each $\mathrm{g} / \mathrm{dL}$ albumin decline will decrease the AG with about $2.5 \mathrm{mEq} / \mathrm{L}$. To appreciate these facts, the AG formule should be: $\left[\mathrm{Na}^{+}\right]-\left[\mathrm{Cl}^{-}\right]-$ $\left[\mathrm{HCO}_{3}^{-}\right]-2.5$ [albumin, in $\mathrm{g} / \mathrm{dL}$ ]. This equation is about zero in health, to stress the balance of ions, and also shows the relevance of albumin as a negative ion.

\section{Normal AG Metabolic Acidosis}

\section{Nomenclature}

In the acid-base literature, a nomenclature has evolved that confused many experienced clinicians as well as trainees and students [8]. Concerning normal AG acidosis, one can find the terms "normal AG," "non-AG," and "hyperchloremic" metabolic acidosis, all three implicating the 
Table 1. Characteristics of normal anion gap (AG) metabolic acidosis diseases

\begin{tabular}{|c|c|c|c|c|c|c|c|c|c|c|}
\hline & $\begin{array}{l}\text { Serum } \\
\text { bicar- } \\
\text { bonate, } \\
\mathrm{mEq} / \mathrm{L}\end{array}$ & $\begin{array}{l}\text { Plasma } \\
\mathrm{K}^{+}\end{array}$ & $\begin{array}{l}\mathrm{Ca}^{2+} \\
\text { excretion }\end{array}$ & $\begin{array}{l}\text { Urine } \\
\mathrm{AG} \\
\mathrm{mEq} / \mathrm{L}\end{array}$ & $\begin{array}{l}\text { Urine osmolol } \\
\text { gap,mosm } / \mathrm{kg} \\
\text { in metabolic } \\
\text { acidosis }\end{array}$ & $\begin{array}{l}\text { Urinary } \\
\mathrm{NH}_{4}^{+}, \\
\mathrm{mEq} / \text { day }\end{array}$ & $\begin{array}{l}\text { Minimal } \\
\text { urine } \\
\mathrm{pH}\end{array}$ & $\begin{array}{l}\text { Ability to } \\
\text { acidify } \\
\text { urine in } \\
\text { response to } \\
\text { acidemia }\end{array}$ & $\begin{array}{l}\text { Urine- } \\
\text { blood } \\
\mathrm{pCO}_{2} \text {, } \\
\mathrm{mm} \mathrm{Hg}\end{array}$ & Comment \\
\hline Health & Normal & Normal & Normal & +20 to +90 & $10-100$ & $30-40$ & $4.5-6$ & Yes & $>30$ & \\
\hline Severe diarrhea & $<24$ & Low & Normal & -20 to -50 & $>200$ & High & $>5.5$ & Yes & & \\
\hline Toluene/hippurate & $<24$ & Low & Normal & Positive & $>200$ & High & & Yes & & \\
\hline $\begin{array}{l}\text { Defective CA II } \\
\text { activity/proximal } \\
\text { RTA (type 2) }\end{array}$ & $12-20$ & $\begin{array}{l}\text { Low/ } \\
\text { normal }\end{array}$ & Normal & $\begin{array}{l}\text { Negative } \\
-20 \text { to }-50\end{array}$ & $>150$ & Normal & $<5.5$ & Yes & & $\begin{array}{l}\text { Urine } \mathrm{pH}>6.5 \text { during } \\
\text { early phase with } \\
\text { bicarbonaturia }\end{array}$ \\
\hline $\begin{array}{l}\text { Fanconi syndrome/ } \\
\text { proximal RTA } \\
\text { (type 2) }\end{array}$ & $12-18$ & Low & $\uparrow$ & $\begin{array}{l}\text { Negative } \\
-20 \text { to }-50\end{array}$ & $>150$ & Normal & $<5.5$ & Yes & & $\begin{array}{l}\text { Hypophosphatemia/ } \\
\text { phosphaturia, } \\
\text { hypouricemia/ } \\
\text { hyperuricosuria } \\
\text { renal glucosuria } \\
\text { (glucosuria with a normal } \\
\text { serum glucose } \\
\text { concentration), } \\
\text { aminoaciduria }\end{array}$ \\
\hline $\begin{array}{l}\text { Hypokalemic distal } \\
\text { RTA (type 1) }\end{array}$ & $10-20$ & Low & $\uparrow$ & Positive & $\begin{array}{l}<150 \\
\text { (usually } \\
<50-100 \text { ) }\end{array}$ & Low & $\begin{array}{l}>5.5 \\
\text { (often } \\
>6.5)\end{array}$ & No & $<30$ & \\
\hline Back diffusion & $8-15$ & Low & $?$ & Positive & $?$ & Low & & No & & \\
\hline $\begin{array}{l}\text { Hyperkalemic distal } \\
\text { RTA (voltage- } \\
\text { dependent RTA) }\end{array}$ & $8-15$ & High & $\begin{array}{l}\text { Normal } \\
\text { or } \uparrow\end{array}$ & Positive & $\begin{array}{l}<150 \\
\text { (usually } \\
<50-100 \text { ) }\end{array}$ & Low & $\begin{array}{l}>5.5 \\
\text { (often } \\
>6.5)\end{array}$ & No & & \\
\hline RTA type 3 & Low & Low & $\uparrow$ & & & Low & $>5.5$ & No & & \\
\hline RTA type 4 & $16-22$ & High & Normal & Positive & $\begin{array}{l}<150 \\
\text { (usually } \\
<50-100 \text { ) }\end{array}$ & Low & $<5.5$ & Yes & & $\begin{array}{l}\text { Often increased } \\
\text { creatinine }\end{array}$ \\
\hline
\end{tabular}

same disorder. However, the verb "non-AG" implicates an AG of zero, which is incorrect because one, in fact, refers to an AG below 10-12 $\mathrm{mEq} / \mathrm{L}$. Hyperchloremia will be present in a patient with shock and dehydration with hypernatriemia, however, with a high AG. Sodium and chloride will increase because of dehydration and little water intake. Hyperchloremic metabolic acidosis is, therefore, not synonymous with a normal AG. Therefore, the preferred terminology is normal AG metabolic acidosis.

Another confusing subject is the so-called "dilution acidosis" suggesting that a fall in serum bicarbonate concentration is solely due to expansion of the extracellular fluid volume with large volumes of intravenous fluids like normal saline. However, dilution acidosis is a misnomer because the reason for the decrease in bicarbonate in chloride-rich fluids is the necessity of electroneutrality and not merely "dilution" of bicarbonate. Therefore, hyperchloremic metabolic acidosis can also be the result of chlorine inhalation [9], because an increased $\mathrm{Cl}^{-} / \mathrm{Na}^{+}$ratio above 0.79 will lead to a normal AG metabolic acidosis $[10,11]$.
The classification of renal tubular acidosis (RTA) may also be confusing as the defect in the proximal and distal tubules is named paradoxically type 2 and type 1 , respectively (Table 1).

\section{Case Definition and Pathophysiology}

In case of a normal AG metabolic acidosis, bicarbonate loss is replaced by chloride and the $\mathrm{AG}$ equation $\left(\left[\mathrm{Na}^{+}\right]-\left[\mathrm{Cl}^{-}\right]-\left[\mathrm{HCO}_{3}^{-}\right]\right)$will, therefore, remain the same, or "normal." In other words, if bicarbonate drops $10 \mathrm{mEq} / \mathrm{L}$ and chloride raises $10 \mathrm{mEq} / \mathrm{L}$, the sum of the anions remains the same. The real question in normal AG metabolic acidosis is consequently: in what circumstances will there be an exchange of bicarbonate and chloride, or - in other words - when will the decrease or loss of bicarbonate be replaced by chloride - to maintain electroneutrality. This exchange of bicarbonate and chloride occurs in diseases of the gastrointestinal tract and the kidneys. 
Gastrointestinal Cause of Normal AG Metabolic

Acidosis

Severe diarrhea is the most common cause of gastrointestinal loss of bicarbonate. Because the concentration of bicarbonate in diarrheal fluid is generally greater than that in plasma, large amounts can be lost in severe diarrhea or ileostomy [12]. Ureteral diversion can also lead to a normal AG metabolic acidosis. Ureteral implantation into the sigmoid colon or the replacement of the urinary bladder using a short loop of ileum will lead to the exposure of urine to the gastrointestinal mucosa, which will cause gastrointestinal bicarbonate loss and retention of chloride [13]. Cholestyramine is a nonabsorbable anion exchange resin used to bind bile acids in the gut. It has been used in the treatment of hypercholesterolemia, pruritus associated with elevated levels of bile acids, and diarrhea due to bile acid malabsorption in the setting of ileal disease or resection [14]. It swaps chloride anions for bile acids in the lumen of the small intestine, resulting in bile acid complexes that are fecal excreted instead of being reabsorbed in the ileum. This exchange causes gastrointestinal secretion of bicarbonate and absorption of chloride. If the kidneys cannot compensate by increasing chloride excretion and bicarbonate retention because of impaired urinary acidification such as renal insufficiency and aldosterone antagonism a normal AG metabolic acidosis develops [14].

\section{Renal Tubular Acidosis}

There are three major forms of RTA: proximal RTA (type 2), distal RTA (type 1), and hyperkalemic RTA (type 4). Hyperkalemic RTAs include hypoaldosteronism (type 4) and a voltage-dependent RTA, which is caused by defects in distal sodium reabsorption and is perhaps a subtype of distal RTA. RTA type 3 is a mixed RTA form of type 1 and type 2 [15].

Tubular defects are inherited or acquired. This review will focus on the acquired forms of RTA.

\section{Proximal Tubule Dysfunction}

To recognize RTA, one should know how tubular dysfunction will lead to metabolic acidosis. The proximal tubule absorbs approximately $85-90 \%$ of the filtered bicarbonate and $60 \%$ of the filtered sodium along with water, phosphate, amino acids, and glucose. The loop of Henle reabsorbs around $10 \%$ of the filtered bicarbonate and the remaining $5-10 \%$ is reabsorbed in the collecting tubules. The process of bicarbonate reabsorption in the distal tubule involves an $\mathrm{HCO}_{3}^{-} / \mathrm{Cl}^{-}$exchanger [16].
Isolated Carbonic Anhydrase Defect

An isolated acquired proximal tubular acid-base defect (RTA type 2) can be caused by failing of the enzyme carbonic anhydrase (CA) IV by enzyme blockers like acetazolamide and topiramate. CAs are a family of zinc metalloenzymes found in all organisms, catalyzing the reversible reaction of $\mathrm{CO}_{2}$ hydration to bicarbonate and a proton [17]. An anhydrase is defined as an enzyme that catalyzes the removal of a water molecule from a compound, and so it is this "reverse" reaction that gives CA its name, because it removes a water molecule from carbonic acid. $\mathrm{H}_{2} \mathrm{CO}_{3}$ is formed in the body by the reaction of $\mathrm{CO}_{2}$ with $\mathrm{H}_{2} \mathrm{O}$ :

$$
\mathrm{H}_{2} \mathrm{O}+\mathrm{CO}_{2} \leftrightarrow \mathrm{H}_{2} \mathrm{CO}_{3} \leftrightarrow \mathrm{H}^{+}+\mathrm{HCO}_{3}^{-} .
$$

This reaction is slow, and small amounts of $\mathrm{H}_{2} \mathrm{CO}_{3}$ are formed unless the enzyme CA is present. This enzyme is especially abundant in the walls of the lung alveoli, where $\mathrm{CO}_{2}$ is released, and also in the epithelial cells of the renal tubules, where $\mathrm{CO}_{2}$ reacts with $\mathrm{H}_{2} \mathrm{O}$ to form $\mathrm{H}_{2} \mathrm{CO}_{3}$. In many organisms, CA enzymes are involved in crucial physiological processes connected with respiration and transport of $\mathrm{CO}_{2} /$ bicarbonate, $\mathrm{pH}$, and $\mathrm{CO}_{2}$ homeostasis, electrolyte secretion in a variety of tissues of organs, biosynthetic reactions (e.g., gluconeogenesis, lipogenesis, and ureagenesis), bone resorption, calcification, tumorigenicity, and many other physiologic or pathologic processes $[16,17]$.

Four different CAs are expressed in the human nephron and two isoforms of CA deficiency have been described (CA II and CA IV) [18]. CA II is cytoplasmic and found in the proximal and distal tubule. CA IV is located in the apical membrane of the proximal tubule. In the proximal tubular lumen, filtered bicarbonate reacts with hydrogen ions to form carbonic acid $\left(\mathrm{H}_{2} \mathrm{CO}_{3}\right)$ that splits into $\mathrm{CO}_{2}$ and $\mathrm{H}_{2} \mathrm{O}$ by the action of luminal enzyme $\mathrm{CA}$ IV. $\mathrm{CO}_{2}$ diffuses back into the cells where it reacts with $\mathrm{H}_{2} \mathrm{O}$ in the presence of cytoplasmic CA II and generates $\mathrm{HCO}_{3}^{-}$and $\mathrm{H}^{+}$. $\mathrm{HCO}_{3}^{-}$is transported into the blood, in exchange of chloride, while $\mathrm{H}^{+}$is secreted into the lumen. Bicarbonate absorption by this mechanism is saturable, so whenever the normal level of $24 \mathrm{mmol} / \mathrm{L}$ is reached, loss of bicarbonate in the urine develops. Under normal conditions, however, there is virtually no bicarbonate in the urine $[17,19]$. Hypokalemia is very common in proximal RTA because of excess urinary loss of $\mathrm{K}^{+}$. This is due to the increased delivery of $\mathrm{Na}^{+}$and $\mathrm{HCO}_{3}^{-}$to the distal nephron, where $\mathrm{Na}^{+} / \mathrm{K}^{+}$exchange occurs. Also, volume depletion induces aldosterone secretion that will contribute to $\mathrm{K}^{+}$wastage. One should realize that proximal RTA
152

Kidney Dis 2017;3:149-159 DOI: $10.1159 / 000479279$
Berend 
Table 2. Causes of renal tubular acidosis (RTA)

\begin{tabular}{|c|c|c|c|c|}
\hline \multicolumn{2}{|l|}{ Causes of proximal RTA } & \multicolumn{2}{|l|}{ Causes of distal RTA } & \multirow[t]{2}{*}{ Causes of RTA type 4} \\
\hline isolated defect & generalized defect & with hypokalemia & with hyperkalemia & \\
\hline $\begin{array}{l}\text { Autosomal dominant } \\
\text { Proximal RTA from } \\
\text { unknown gene mutation }\end{array}$ & $\begin{array}{l}\text { Primary (genetic) inborn errors of } \\
\text { metabolism } \\
\text { (Cystinosis, Wilson disease, } \\
\text { galactosemia, hereditary fructose } \\
\text { intolerance, methylmalonic acidemia, } \\
\text { glycogen storage diseases) }\end{array}$ & $\begin{array}{l}\text { Calcium-induced tubular damage } \\
\text { Idiopathic hypercalciuria } \\
\text { Primary hyperparathyroidism } \\
\text { Hypervitaminosis D } \\
\text { Medullary sponge kidney }\end{array}$ & & \\
\hline $\begin{array}{l}\text { Autosomal recessive } \\
\text { Sodium bicarbonate symporter } \\
\text { (NBC1) protein mutation in the } \\
\text { SLC4A4 gene }\end{array}$ & $\begin{array}{l}\text { Dysproteinemic states } \\
\text { (Myeloma, } \\
\text { monoclonal gammopathy) }\end{array}$ & $\begin{array}{l}\text { Autoimmune diseases } \\
\text { Sjögren syndrome } \\
\text { Rheumatoid arthritis } \\
\text { SLE } \\
\text { Polyarteritis nodosa } \\
\text { Thyroiditis } \\
\text { Primary biliary cirrhosis } \\
\text { Chronic active hepatitis } \\
\text { Cryoglobulinemia }\end{array}$ & $\begin{array}{l}\text { Decreased effective } \\
\text { intravascular volume of any } \\
\text { cause } \\
\text { Sickle cell disease } \\
\text { Urinary tract obstruction } \\
\text { SLE } \\
\text { Renal transplant rejection } \\
\text { Amyloidosis }\end{array}$ & $\begin{array}{l}\text { Aldosterone deficiency } \\
\text { Addison disease } \\
\text { 21-Hydroxylase deficiency } \\
\text { Hyporeninemia } \\
\text { Diabetic nephropathy } \\
\text { Tubulointerstitial disease } \\
\text { HIV } \\
\text { IgM monoclonal gammopathy }\end{array}$ \\
\hline \multirow[t]{7}{*}{$\begin{array}{l}\text { Inherited CA II deficiency caused } \\
\text { by mutations in the CA2 } \\
\text { gene - associated with mental } \\
\text { retardation, cerebral } \\
\text { calcifications and osteopetrosis } \\
\text { (Sly syndrome) }\end{array}$} & Honeybee stings & $\begin{array}{l}\text { Idiopathic causes } \\
\text { Marfan syndrome } \\
\text { Wilson disease } \\
\text { Ehlers-Danlos syndrome }\end{array}$ & & $\begin{array}{l}\text { Aldosterone resistance } \\
\text { Obstructive uropathy } \\
\text { Sickle cell nephropathy } \\
\text { Amyloidosis } \\
\text { Diabetic nephropathy } \\
\text { Lupus nephritis } \\
\text { Pseudohypoaldosteronism }\end{array}$ \\
\hline & $\begin{array}{l}\text { Secondary } \\
\text { hyperparathyroidism } \\
\text { with chronic hypocalcemia } \\
\text { Vitamin D deficiency }\end{array}$ & & & \\
\hline & $\begin{array}{l}\text { Tubulointerstitial diseases } \\
\text { (Sjögren syndrome, } \\
\text { medullary cystic disease, } \\
\text { renal transplantation) }\end{array}$ & & & \\
\hline & Nephrotic syndrome & & & \\
\hline & Amyloidosis & & & \\
\hline & $\begin{array}{l}\text { Paroxysmal nocturnal } \\
\text { hemoglobinuria }\end{array}$ & & & \\
\hline & $\begin{array}{l}\text { Toxins (lead, mercury, } \\
\text { copper, cadmium, } \\
\text { glue sniffing) }\end{array}$ & & & \\
\hline \multicolumn{2}{|l|}{ Drugs as causes of proximal RTA } & \multicolumn{2}{|l|}{ Drugs as causes of distal RTA } & Drugs as causes of RTA type 4 \\
\hline isolated defect & generalized defect & with hypokalemia & & \\
\hline CA inhibitors & $\begin{array}{l}\text { Ifosfamide, aminoglycosides, expired } \\
\text { tetracycline, streptozocin, azacitidine } \\
\text { (antimetabolites), mercaptopurine, } \\
\text { valproic acid, ranitidine, lead, } \\
\text { cadmium, mercury, antiretroviral } \\
\text { drugs, propylene glycol-containing } \\
\text { drugs }\end{array}$ & $\begin{array}{l}\text { Amphotericin B, lithium } \\
\text { carbonate, methicillin (meticillin), } \\
\text { foscarnet, ifosfamide, toluene }\end{array}$ & & $\begin{array}{l}\text { Reduced } \mathrm{NH}_{4}^{+} \text {production } \\
\text { (hypoaldosteronism) } \\
\mathrm{K}^{+} \text {-sparing diuretics } \\
\text { (spironolactone, eplerenone, } \\
\text { amiloride, triamterene), } \\
\text { cotrimoxazole, ACEI, } \\
\text { angiotensin II receptor type } 1 \\
\text { antagonists, renin inhibitors, } \\
\text { NSAIDs, ciclosporin, } \\
\text { tacrolimus, heparin }\end{array}$ \\
\hline
\end{tabular}

ACEI, angiotensin-converting enzyme inhibitors; CA, carbonic anhydrase; SLE, systemic lupus erythematosus.

is a self-limiting disorder and bicarbonate wasting can be transient depending on the intake of bicarbonate-forming substances. Because the bicarbonate reabsorptive capacity is reduced from the normal level of approximately $24 \mathrm{mEq} / \mathrm{L}$, a new steady state will be present as all the filtered bicarbonate can now be reabsorbed, and the patient is able to excrete the daily acid load. However, the bicar-

Normal Anion Gap Metabolic Acidosis bonate concentration will remain low as the urinary bicarbonate wasting continues until the plasma $\mathrm{HCO}_{3}^{-}$level reaches a new low level of about $12-18 \mathrm{mEq} / \mathrm{L}[20,21]$. The plasma bicarbonate concentration usually does not fall below $12 \mathrm{mEq} / \mathrm{L}$ in patients with proximal RTA as distal renal tubules have substantial bicarbonate reabsorptive capacity [21]. 


\section{Fanconi Syndrome}

A generalized proximal tubular dysfunction may cause the so-called Fanconi syndrome characterized by a complex transport defect of the proximal tubule that results in decreased reabsorption of glucose, amino acids, bicarbonate, uric acid, and phosphate. Therefore, bicarbonaturia, tubular proteinuria, aminoaciduria, phosphaturia, glucosuria, and uric acid and sodium wasting may be present [22]. Fanconi syndrome can occur as an inborn error or an acquired disorder, including multiple myeloma and specific medications, including tenofovir and ifosfamide (Table 2).

\section{Distal Tubular Dysfunction}

In the distal tubules, acid excretion $\left(\mathrm{H}^{+}\right)$is counterbalanced by $\mathrm{K}^{+}$retention, by $\mathrm{H}^{+} / \mathrm{K}^{+}$ATPase, leading to hypokalemia and metabolic acidosis when there is a defect in this exchange. Another defect may be an increased permeability of the luminal membranes to secreted protons. This results in back diffusion of $\mathrm{H}^{+}$despite the presence of an effective pump. This gradient defect is classically seen in patients treated with amphotericin B $[23,24]$. Before the back diffusion occurs, the secreted $\mathrm{H}^{+}$ions in the tubular lumen bind $\mathrm{HCO}_{3}^{-}$to form $\mathrm{H}_{2} \mathrm{CO}_{3}$. As there is no luminal CA, $\mathrm{H}_{2} \mathrm{CO}_{3}$ is slowly dehydrated to $\mathrm{CO}_{2}$ and water causing transient high urine $\mathrm{pCO}_{2}$ levels. This is the only type of classic RTA with high urine $\mathrm{pCO}_{2}$ levels (>65 $\mathrm{mm} \mathrm{Hg}$ ) and corresponding high urine-blood $\mathrm{pCO}_{2}$ difference $(>25 \mathrm{~mm} \mathrm{Hg})$ [23]. A small number of patients with distal RTA have a voltage defect in the distal tubules leading to hyperkalemia rather than hypokalemia [24]. The necessary transepithelial voltage gradient for the exchange of $\mathrm{H}^{+} / \mathrm{K}^{+}$cannot be maintained, forcing retention of both $\mathrm{K}^{+}$and $\mathrm{H}^{+}$in exchange for $\mathrm{Na}^{+}$, as can be seen in aldosterone-related RTA type 4 (discussed below). The entities are distinct because, in contrast with distal RTA due to a voltage defect in the distal tubules, patients with RTA type 4 maintain their ability to acidify urine in response to acidemia [24].

\section{RTA Type 4}

Aldosterone plays an essential role in the maintenance of fluid and electrolyte homeostasis in the collecting duct, where $\mathrm{Na}^{+}$is exchanged for $\mathrm{H}^{+}$and $\mathrm{K}^{+}$. The kidney accounts for about $90 \%$ of excreted potassium, primarily governed by plasma aldosterone and delivery of sodium and water to the distal secretory site. Hypoaldosteronism (RTA type 4) is caused by reductions in aldosterone secretion or responsiveness resulting in an increase in plasma $\mathrm{H}^{+}$and $\mathrm{K}^{+}$concentrations. Well-known causes are chronic interstitial nephritis and the most common RTA type: hyporeninemic hypoaldosteronism due to diabetic nephropathy. Many drugs will decrease the activity of aldosterone, including angiotensin-converting enzyme inhibitors, angiotensin II receptor blockers, and direct renin inhibitors (Table 2) [23].

\section{Normal AG Acidosis due to Saline Infusion}

Numerous severely ill patients admitted to the hospital will develop an iatrogenic normal AG metabolic acidosis caused by fluid resuscitation with normal saline (NaCL 0.9\%). As an example, all patients with severe diabetic ketoacidosis treated with $\mathrm{NaCl} 0.9 \%$ will have a combined high AG and normal AG metabolic acidosis soon after admission [29]. Hyperchloremia develops rapidly, increasing to $50 \%$ by $4 \mathrm{~h}$ in a previous study [25]. Patients treated with therapeutic plasma exchange with a replacement solution of $4 \%$ human albumin with a high chloride concentration can also develop a normal AG metabolic acidosis [26]. Another rare cause in this respect may be the use of $\mathrm{NaCl} 0.9 \%$ for total gut irrigation through the nasogastric route method as a bowel preparation in children undergoing colorectal surgeries [27]. Normal saline has a $\mathrm{pH}$ of 5.5 and a chloride content of $154 \mathrm{mmol} / \mathrm{L}$ and sodium of $154 \mathrm{mmol} / \mathrm{L}$. The low $\mathrm{pH}$ has little influence on the development of acidosis after resuscitation. Because plasma has a sodium content of about $140 \mathrm{mmol} / \mathrm{L}$ and much lower chloride content of about $106 \mathrm{mmol} / \mathrm{L}$, the chloride increase will be relatively higher than the sodium increase with the infusion of $\mathrm{NaCl} 0.9 \%$. Because of this increase in chloride, a decrease in bicarbonate follows to maintain electroneutrality. Serum chloride is responsible for about one third of the extracellular fluid tonicity and two thirds of all anionic charges in plasma. Because of its high concentration, chloride is the most important anion to balance extracellular cations [28]. All bodily fluids conform to the principle of electrical neutrality, containing an equivalent number of positively and negatively charged ions. Therefore, to maintain electrical neutrality in the face of rising serum chloride anions from normal saline, the serum loses an equal amount of bicarbonate anions resulting in normal AG metabolic acidosis [29].

\section{Diagnostic Evaluation of Normal AG Acidosis}

Functional Tests

The first step is to exclude severe diarrhea or the use of medications that can cause RTA. 
Urinary Ammonium/Urine AG

If the kidney function is intact, hyperchloremic acidosis should lead to increased renal excretion of ammonium, and measurement of urinary ammonium can, therefore, be used to differentiate between renal and extrarenal causes of normal AG acidosis. However, since few laboratories measure urinary ammonium routinely, the urinary $\mathrm{AG}\left(\left[\mathrm{Na}^{+}\right]+\left[\mathrm{K}^{+}\right]-\left[\mathrm{Cl}^{-}\right]\right)$and urinary osmolal gap $\left(\left[\mathrm{Na}^{+}\right]+\left[\mathrm{K}^{+}\right]+\right.$glucose $+\mathrm{BUN}-\left[\mathrm{Cl}^{-}\right]$in $\left.\mathrm{mmol} / \mathrm{l}\right)$ are often used as surrogate measures of excretion of urinary ammonium $[30,31]$. When individuals ingest a typical western diet, the quantity of sodium and potassium absorbed by the gastrointestinal tract will be higher than the absorbed chloride, and the urine AG will have a positive value (about +20 to $+90 \mathrm{mmol} / \mathrm{L}$ ) in healthy individuals. Ammonium is excreted as $\mathrm{NH}_{4} \mathrm{Cl}$, and, therefore, the chloride excretion should be high in metabolic acidosis and the urinary AG $\left(\left[\mathrm{Na}^{+}\right]+\left[\mathrm{K}^{+}\right]-\left[\mathrm{Cl}^{-}\right]\right)$must become negative in severe diarrhea (about -30 to -50 $\mathrm{mEq} / \mathrm{L})$. In RTA type 1 and type 4 , the urine AG will become positive because of the low chloride excretion as a result of the impaired urinary ammonium $\left(\mathrm{NH}_{4}^{+}\right)$excretion as ammonium chloride $\left[\mathrm{NH}_{4} \mathrm{Cl}\right]$ ). This defect can be seen in renal failure, distal RTA, or hypoaldosteronism $[30,31]$. In proximal RTA, bicarbonate resorption is defective, but the ammonium excretion remains intact, and, therefore, a negative urinary AG will be found in RTA type 2 [32].

\section{The Urinary Osmolal Gap}

The urinary AG becomes unreliable when polyuria is present, when the urine $\mathrm{pH}$ exceeds 6.5 [31], or when urinary ammonium is excreted with an anion other than chloride (e.g., keto acids, acetylsalicylic acid, D-lactic acid, and large quantities of penicillin [30]. Furthermore, the acidification of the urine requires adequate distal delivery of sodium; thus, the usefulness of the urinary AG is questionable when the urinary sodium level is less than 20 $\mathrm{mmol} / \mathrm{L}$ [33]. In such cases, the urinary osmolal gap is generally more reliable. The urinary osmolal gap determines the difference between measured and calculated urinary osmolality. The urinary osmolality is calculated as follows: $\left(2\left[\mathrm{Na}^{+}\right]+2\left[\mathrm{~K}^{+}\right]\right)+$(urine urea nitrogen [in $\mathrm{mg} / \mathrm{dL}] / 2.8$ ) + (urine glucose [in $\mathrm{mg} / \mathrm{dL}] / 18$ ) or (in mmol/L): $\left(2\left[\mathrm{Na}^{+}\right]+2\left[\mathrm{~K}^{+}\right]\right)+($urine urea nitrogen $)+$ (urine glucose). In patients without diabetes, the glucose concentration is often omitted from this calculation. A normal urine osmolal gap is approximately 10-100 mosm $/ \mathrm{kg}$, with urinary ammonium excretion being approximately one half of this value $(5-50 \mathrm{mmol} / \mathrm{L})$ due to

Normal Anion Gap Metabolic Acidosis accompanying anions. A high urine osmolal gap $>200$ $\mathrm{mEq} / \mathrm{L}$ suggests a high urine ammonium concentration, and a nonrenal cause for the acidosis like diarrhea (often $>300-400 \mathrm{mEq} / \mathrm{l})$ is more likely than RTA $[34,35]$. A urinary osmolal gap below $40 \mathrm{mmol}$ per liter in normal anion-gap acidosis indicates impairment in urinary ammonium excretion. The urinary osmolal gap usually reflects the level of ammonium, except in the presence of large quantities of a nondissociated acid, such as $\beta$-hydroxybutyric acid in ketoacidosis and hippurate in toluene intoxication. The urinary osmolal gap, as compared with the urinary AG, has a better correlation with the urinary ammonium value $[30,31]$.

\section{Urine $\mathrm{pH}$}

The urine $\mathrm{pH}$ reflects the hydrogen ion concentration and, therefore, the degree of acidification of the urine. Because urine can achieve a hydrogen ion concentration $1,000 \times$ greater than blood, its $\mathrm{pH}$ ranges from 4.5 to 8 (average pH 5-6) [36]. Though the gold standard of measurement is with a $\mathrm{pH}$ electrode, dipsticks offer the convenience of cost and ease of use [37]. However, many limitations concerning the urine $\mathrm{pH}$ level exist. The $\mathrm{pH}$ determined by dipsticks covers a $\mathrm{pH}$ range from 5.0 to 8.5 or to 9.0. Using dipsticks, however, significant deviations from the true $\mathrm{pH}$ are observed for values below 5.5 and above 7.5 [38]. The $\mathrm{pH}$ of urine is dependent on the time of day, the prandial state, diet, health status, and medications. A high protein diet is associated with acidic urine, and a vegetarian diet typically produces more alkaline urine because of bicarbonate formation from fruits, especially citrus, and vegetables. Highly diluted urine and a very low concentration of urinary sodium may interfere with the achievement of a minimum $\mathrm{pH}$ despite a normal renal acidification function. Often, the urine specimen becomes contaminated preanalytically with bacteria during collection [36]. While midstream urine collection after cleansing of the genitalia may be the preferred method, most urine collections are made without this practice. Both the male and female urethras are colonized with microorganisms. While urine collected by conventional voiding is often bacterially contaminated, even midstream random urine collections, whether with or without prior cleansing of external genitalia, have bacterial contamination rates of up to $30 \%[36,38]$. Left standing, the $\mathrm{pH}$ of a bacterial-contaminated, unpreserved urine specimen will continue to increase. Bacterial contamination of urine with microorganisms that split urea may yield urinary $\mathrm{pH}$ values $>8.0$ because of bacterial decomposition of urea to ammonia. A urea-splitting microor-

Kidney Dis 2017;3:149-159 DOI: $10.1159 / 000479279$ 
ganism can produce alkaline urine through the following mechanism [36]:

Urea $\left(\mathrm{H}_{2} \mathrm{NCONH}_{2}\right)+\mathrm{H}_{2} \mathrm{O} \rightarrow 2 \mathrm{NH}_{3}+\mathrm{CO}_{2} \rightarrow 2 \mathrm{NH}_{4}^{+}+2 \mathrm{OH}^{-}$.

Therefore, the measurement of $\mathrm{pH}$ in fresh urine samples and a $\mathrm{pH}$ meter should be used if an accurate measurement is necessary.

In metabolic acidosis and acidemia, the urine $\mathrm{pH}$ should decrease below 5.3 when the kidney function is intact. A higher value may indicate the presence of RTA. A normal adult under a common western diet eliminates about 40 $\mathrm{mEq} /$ day of $\mathrm{NH}_{4}^{+}$. In case of chronic metabolic acidosis, the urinary $\mathrm{NH}_{4}^{+}$can increase up to 5-8 times the normal value, causing a maximum decrease in the urine $\mathrm{pH}$ to 4.5 [40]. Sometimes, it may be challenging to differentiate between diarrhea and distal RTA as a cause of normal AG acidosis and an elevated urine $\mathrm{pH}$. Hypokalemia due to diarrhea can result in an inappropriately elevated urine $\mathrm{pH}$ that is due to a decrease in collecting duct $\mathrm{H}^{+}$secretion because hypokalemia is a potent stimulus of renal $\mathrm{NH}_{3}$ production. The excess $\mathrm{NH}_{3}$ in the urine binds to secreted $\mathrm{H}^{+}$, thereby elevating the urine $\mathrm{pH}$ despite adequate tubular $\mathrm{H}^{+}$ secretion. When the hypokalemia is treated, $\mathrm{H}^{+}$production by the kidney decreases, and the urine $\mathrm{pH}$ decreases appropriately. In contrast, in distal RTA (type 1), correction of hypokalemia has no effect on urine $\mathrm{pH}$ [41].

\section{Ammonium Chloride Load}

Administration of $\mathrm{NH}_{4} \mathrm{Cl}$ to induce metabolic acidosis with assessment of the renal response by serial measurement of urine $\mathrm{pH}$ has been often utilized in the past. It has classically been considered a crucial test in the diagnosis of distal RTA. Nowadays, its clinical application is quite restricted because the $\mathrm{NH}_{4} \mathrm{Cl}$ test is poorly tolerated since it induces nausea and vomiting. Also, the ability to acidify the urine may be assessed with less aggressive explorations [42].

Furosemide and Fludrocortisone

An alternative way to test the capacity for distal acidification is to administer furosemide and the mineralocorticoid fludrocortisone simultaneously [39]. The combination of both increased distal $\mathrm{Na}^{+}$delivery, and the mineralocorticoid effect will stimulate distal $\mathrm{H}^{+}$secretion by both an increase in the luminal electronegativity and a direct stimulation of $\mathrm{H}^{+}$secretion. Normal subjects will lower urine $\mathrm{pH}$ to values below 5.5 with either maneuver $[39,42]$.

The Urine-Blood $\mathrm{pCO}_{2}$ during $\mathrm{NaHCO}_{3}$ Loading

Urine $\mathrm{pCO}_{2}$ after alkalization is a measure of the capacity of the proton pump to maximally secrete $\mathrm{H}^{+}$be- cause alkaline urine provides a favorable gradient for $\mathrm{H}^{+}$ secretion. The urine-blood $\mathrm{pCO}_{2}$ during $\mathrm{NaHCO}_{3}$ loading is, therefore, an excellent diagnostic index of $\mathrm{H}^{+}$ATPase defect distal RTA [43]. In the $\mathrm{NaHCO}_{3}$ loading test, $2.75 \% \mathrm{NaHCO}_{3}$ solution should be infused intravenously at a rate of $4 \mathrm{~mL} / \mathrm{kg} / \mathrm{h}$. Urine and blood samples are taken at 2-h intervals until the plasma bicarbonate concentration reaches $24 \mathrm{mmol} / \mathrm{L}$. Urine and blood $\mathrm{pCO}_{2}$ are measured then using a blood gas analyzer. The urine-blood $\mathrm{pCO}_{2}$ is $\leq 30 \mathrm{~mm} \mathrm{Hg}$ in patients with distal RTA and $\mathrm{H} \mathrm{H}^{+}$-ATPase defect but $>30 \mathrm{~mm} \mathrm{Hg}$ in health.

\section{Bicarbonate Load}

When patients are in a steady state and there is no hypokalemia, sodium bicarbonate $0.5-1.0 \mathrm{mEq} / \mathrm{kg} / \mathrm{h}$ can be infused until the plasma $\mathrm{HCO}_{3}^{-}$increases to the threshold and bicarbonaturia ensues resulting in a high urine $\mathrm{pH}$ and high fractional $\mathrm{HCO}_{3}^{-}$excretion [21]:

$$
\text { Fractional } \mathrm{HCO}_{3} \text { excretion }=\frac{\left(\text { urine } \mathrm{HCO}_{3}^{-}\right) \times(\text {plasma creatinine })}{\left(\text { plasma } \mathrm{HCO}_{3}^{-}\right) \times(\text {urine creatinine })} \times 100 .
$$

A urine $\mathrm{pH}>7.5$ or fractional excretion of $\mathrm{HCO}_{3}^{-}>15 \%$ is diagnostic of proximal RTA after bicarbonate loading. Urine $\mathrm{pH}$ will be unchanged in normal patients or those with distal RTA. A fractional excretion of $\mathrm{HCO}_{3}^{-}<5 \%$ excludes proximal RTA, and a value of $5-15 \%$ is indeterminate.

\section{Decreased or Negative AG with or without Acidosis}

\section{Increased Concentration of Cations}

The result of the equation $\left[\mathrm{Na}^{+}\right]-\left[\mathrm{Cl}^{-}\right]-\left[\mathrm{HCO}_{3}^{-}\right]$will become low in several clinical cases where the measured chloride increases. To maintain electrical neutrality, hyperchloremia develops when high levels of cations exist, as seen in lithium toxicity, monoclonal IgG gammopathy, or disorders characterized by high levels of calcium or magnesium.

\section{Pseudohyperchloremia}

Pseudohyperchloremia is a phenomenon where there is a normal actual chloride concentration, but a high laboratory result is obtained for a chloride assay due to interference by a "chloride look-alike" in the form of a halogen ion such as bromine $\left[\mathrm{Br}^{-}\right]$or iodine $\left[\mathrm{I}^{-}\right]$. In these cases, chloride measurements, up to $175 \mathrm{mEq} / \mathrm{L}$ and an $\mathrm{AG}$ as low as -55 have been reported $[44,45]$. Salicylates can potentially represent another cause for falsely elevated chloride levels and thus an extremely negative AG [46].
156

Kidney Dis 2017;3:149-159

DOI: $10.1159 / 000479279$
Berend 


\section{Practical Considerations}

To bring the above information into practice, 3 case examples are discussed.

\section{Patient 1}

A 60-year-old man was admitted to the surgery ward for an inguinal hernia operation. He was known with long-standing diabetes mellitus type 2 , with retinopathy and incompliance. His medication consisted of insulin, amlodipine, and simvastatin. On examination, the blood pressure was 133/94 $\mathrm{mm} \mathrm{Hg}$ and edema was present. The remainder of the examination was unrevealing. The hemoglobin was $11 \mathrm{~g} \%$, sodium $139 \mathrm{mEq} / \mathrm{L}$, potassium 5.9 $\mathrm{mEq} / \mathrm{L}$, creatinine $19 \mathrm{mg} \%$, and glucose $176 \mathrm{mg} \%$; urine dipstick was albumin positive.

Discussion. We are often confronted with insufficient information, so we must make a tentative diagnosis to guide further evaluation. In this case, the combination of moderate diabetic retinopathy, diabetic nephropathy with proteinuria, and hyperkalemia without prescription of drugs directly affecting the renin-angiotensin-aldosterone system, the diagnosis of RTA type 4 is almost certain. The most important causal factor of chronic hyperkalemia in patients with diabetes is the syndrome of hyporeninemic hypoaldosteronism [47]. In one study, RTA type 4 was very common in patients having significant hyperkalemia, with an incidence of $42 \%$ in patients admitted to a university hospital with a potassium level $\geq 6$ $\mathrm{mEq} / \mathrm{L}$ [48]. In our patient, other laboratory results were: $\mathrm{Na} 138 \mathrm{mEq} / \mathrm{L}$, K $6.4 \mathrm{mEq} / \mathrm{L}$, chloride $113 \mathrm{mEq} / \mathrm{L}$, arterial blood gas: $\mathrm{pH}$ 7.36, $\mathrm{pCO}_{2} 35 \mathrm{~mm} \mathrm{Hg}, \mathrm{pO}_{2} 109 \mathrm{~mm}$ $\mathrm{Hg}$, bicarbonate $19 \mathrm{mEq} / \mathrm{L}$, albumin $2.0 \mathrm{~g} / \mathrm{dL}$, urine $\mathrm{pH}$ 6.3 , glucose negative, and spot urine $\mathrm{Na} 61 \mathrm{mEq} / \mathrm{L}, \mathrm{K} 35$ $\mathrm{mEq} / \mathrm{L}$, and chloride $57 \mathrm{mEq} / \mathrm{L}$ on the next day. The serum $A G$ is $6 \mathrm{mEq} / \mathrm{L}$; to correct it for albumin, one should add $2.5 \mathrm{mEq} / \mathrm{L}$ per $\mathrm{g} / \mathrm{dL}$ albumin to the calculated $\mathrm{AG}$, so in this case add $5 \mathrm{mEq} / \mathrm{L}$. An AG of $11 \mathrm{mEq} / \mathrm{L}$ is probably normal. Therefore, we have a normal AG metabolic acidosis, with urine AG $\left(\mathrm{Na}^{+}-\mathrm{K}^{+}-\mathrm{Cl}^{-}\right)=61+37-57=$ $40 \mathrm{mEq} / \mathrm{L}$. A positive urine AG adds to the diagnosis of RTA type 4.

\section{Patient 2}

You are consulted for a patient with diabetic ketoacidosis because of decreasing bicarbonate level during therapy. Laboratory results of days 1 and 2 are listed in Table 3. On day 2, the AG was increased $3 \mathrm{mEq} / \mathrm{L}$ and bicarbonate was decreased $9 \mathrm{mEq} / \mathrm{L}$. In ketoacidosis, we ex-

Normal Anion Gap Metabolic Acidosis
Table 3. Laboratory results of patient 2

\begin{tabular}{lrc}
\hline Plasma concentration & Day 1 & Day 2 \\
\hline Sodium & 133 & 137 \\
Chloride & 96 & 107 \\
Bicarbonate (used normal value $24 \mathrm{mEq} / \mathrm{L}$ ) & 17 & 15 \\
Anion gap (used upper value $12 \mathrm{mEq} / \mathrm{L}$ ) & 20 & 15 \\
\hline
\end{tabular}

pect that the increase in AG is about the same as the decrease in bicarbonate. Because the bicarbonate was substantially lower than expected on day 2 , there must be a high and normal AG metabolic acidosis. The latter is caused by saline infusions. We must know this so-called delta-delta concept has many limitations [49].

\section{Patient 3}

A female patient was admitted to hospital because of intermittent vomiting, weight loss, and dizziness. She was treated for 18 years with HIV, and, recently, her CD4 count was high and the viral load very low. She was dehydrated, and laboratory tests revealed a plasma sodium of $138 \mathrm{mEq} / \mathrm{L}$, chloride of $110 \mathrm{mEq} / \mathrm{L}$, and glucose $110 \mathrm{mg} \%$. An important clue was provided by the urine dipstick: glucose in the urine was high, while the serum glucose was normal. The serum chloride level was out of proportion for the sodium level with a $\mathrm{CL}^{-} / \mathrm{Na}^{+}$ratio above 0.79 (0.797) suggesting a normal AG metabolic acidosis. The renal glucosuria was pointing to a proximal RTA, and, indeed, the bicarbonate level was $17 \mathrm{mEq} / \mathrm{L}$, and low levels of uric acid and phosphate were noticed. After oral administration of sodium bicarbonate, the urine $\mathrm{pH}$ increased from 6.5 to 7.5 , and bicarbonaturia was also confirmed quantitatively. In this case, tenofovir caused the proximal RTA, and after termination of the drug the patient recovered completely.

\section{Conclusion}

As can be seen by the 3 cases, making a diagnosis in normal AG metabolic acidosis is quite straightforward with clinical signs and additional simple laboratory tests (Tables 1,2). The presence of RTA should be considered in any patient with a high chloride level, in particular when the $\mathrm{CL}^{-} / \mathrm{Na}^{+}$ratio is above 0.79 and the patient does not have diarrhea. In patients with significant hyperkalemia, especially in diabetic patients with a relatively conserved renal function, one should evaluate for RTA type 4. A still growing list of medications can produce RTA. 


\section{Acknowledgment}

I am indebted to Jan-Willem Boldingh for making the gamblegram (Fig. 1).

\section{Conflict of Interest Statement}

The author has no conflict of interest to disclose.

\section{References}

1 Berend K, de Vries AP, Gans RO: Physiologi$\mathrm{cal}$ approach to assessment of acid-base disturbances. N Engl J Med 2015;372:195.

2 Kraut JA, Madias NE: Serum anion gap: its uses and limitations in clinical medicine. Clin J Am Soc Nephrol 2007;2:162-174.

3 Roberts WL, Johnson RD: Serum anion gap. Has the reference value really fallen? Arch Pathol Lab Med 1997;121:568-572.

4 Sadjadi SA, Manalo R, Jaipaul N, McMillan J: Ion-selective electrode and anion gap range: What should the anion gap be? Int J Nephrol Renovasc Dis 2013;6:101-105.

5 Farwell WR, Taylor EN: Serum anion gap, bicarbonate and biomarkers of inflammation in healthy individuals in a national survey. CMAJ 2010;182:137-141.

6 Gamble JL: Extracellular fluid and its maintenance. N Engl J Med 1936;250:1150-1152.

7 Kelly A, McAlpine R, Elizabeth E: Agreement between bicarbonate measured on arterial and venous blood gases. Emerg Med Australas 2004;16:407-409.

8 Berend K: Acid-base pathophysiology after 130 years: confusing, irrational and controversial. J Nephrol 2013;26:254-265.

9 Szerlip HM, Singer I: Hyperchloremic metabolic acidosis after chlorine inhalation. Am J Med 1984;77:581-582.

10 Durward A, Skellett S, Mayer A, Taylor D, Tibby SM, Murdoch IA: The value of the chloride: sodium ratio in differentiating the aetiology of metabolic acidosis. Intensive Care Med 2001;27:828-835.

11 Berend K, van Hulsteijn LH, Gans RO: Chloride: the queen of electrolytes? Eur J Intern Med 2012;23:203-211

12 Ratnam S, Kaeny W, Shapiro JI: Pathogenesis and management of metabolic acidosis and alkalosis; in Schrier RW (ed): Renal and Electrolyte Disorders, ed 7. Philadelphia, Lippincott, Williams \& Wilkins, 2010, pp 86-121.

13 Hall MC, Koch MO, McDougal WS: Metabolic consequences of urinary diversion through intestinal segments. Urol Clin North Am 1991;18:725-735.

14 Kamar FB, McQuillan RF: Hyperchloremic metabolic acidosis due to cholestyramine: a case report and literature review. Case Rep Nephrol 2015;309791.

15 Santos F, Ordóñez FA, Claramunt-Taberner D, Gil-Peña H: Clinical and laboratory approaches in the diagnosis of renal tubular acidosis. Pediatr Nephrol 2015;30:2099-2107.
16 Aggarwal M, McKenna R: Update on carbonic anhydrase inhibitors: a patent review (2008-2011). Expert Opin Ther Pat 2012;22: 903-915.

17 Supuran CT: How many carbonic anhydrase inhibition mechanisms exist? J Enzyme Inhib Med Chem 2016;31:345-360.

18 Oosterwijk E: Carbonic anhydrase expression in kidney and renal cancer: implications for diagnosis and treatment. Subcell Biochem 2014;75:181-198.

19 Curthoys NP, Moe OW: Proximal tubule function and response to acidosis. Clin J Am Soc Nephrol 2014;9:1627-1638.

20 Rennke H, Denker BM: Renal Pathophysiology, ed 4. Philadelphia, Lippincott Williams \& Wilkins, 2014, chapt 6: Metabolic Acidosis, pp 153-173.

21 Reddy P: Clinical approach to renal tubular acidosis in adult patients. Int $\mathrm{J}$ Clin Pract 2011;65:350-360.

22 Garashi T, Sekine T, Inatomi J, Seki G: Unraveling the molecular pathogenesis of isolated proximal renal tubular acidosis. J Am Soc Nephrol 2002;13:2171-2177.

23 Liamis G, Milionis HJ, Elisaf M: Pharmacologically-induced metabolic acidosis. Drug Saf 2010;33:371-391.

24 Yaxley J, Pirrone C: Review of the diagnostic evaluation of renal tubular acidosis. Ochsner J 2016;16:525-530.

25 Taylor D, Durward A, Tibby SM, Thorburn K, Holton F, Johnstone IC, Murdoch IA: The influence of hyperchloraemia on acid base interpretation in diabetic ketoacidosis. Intensive Care Med 2006;32:295-301.

26 Ritzenthaler T, Grousson S, Dailler F: Hyperchloremic metabolic acidosis following plasma exchange during myasthenia gravis crisis. J Clin Apher 2016;31:479-480.

27 Bala I, Dwivedi D, Jain D, Mahajan JK: Hyperchloremic metabolic acidosis following total gut irrigation with normal saline in pediatric patients: a rare occurrence. Indian J Crit Care Med 2017;21:55-56.

28 Thongprayoon C, Cheungpasitporn W, Cheng Z, Qian Q: Chloride alterations in hospitalized patients: prevalence and outcome significance. PLoS One 2017;12:e174430.

29 Mahler SA, Conrad SA, Wang H, Arnold TC: Resuscitation with balanced electrolyte solution prevents hyperchloremic metabolic acidosis in patients with diabetic ketoacidosis. Am J Emerg Med 2011;29:670-674.
30 Reddy P, Mooradian AD: Clinical utility of anion gap in deciphering acid-base disorders. Int J Clin Pract 2009;63:1516-1525.

31 Rodriguez Soriano J: Renal tubular acidosis: the clinical entity. J Am Soc Nephrol 2002;13: 2160-2170.

32 Katzir Z, Dinour D, Reznik-Wolf H, Nissenkorn A, Holtzman E: Familial pure proximal renal tubular acidosis - a clinical and genetic study. Nephrol Dial Transplant 2008;23: 1211-1215.

33 Finkel KW, Dubose TF: Metabolic acidosis; in Dubose T Jr, Hamm L (eds): Acid Base and Electrolyte Disorders: A Companion to Brenner \& Rector's, The Kidney. Philadelphia, Saunders, 2002, pp 55-66.

34 Rastegar M, Nagami GT: Non-anion gap metabolic acidosis: a clinical approach to evaluation. Am J Kidney Dis 2017;69:296-301.

35 Soleimani M, Rastegar A: Pathophysiology of renal tubular acidosis: core curriculum. Am J Kidney Dis 2016;68:488-498.

36 Cook JD, Strauss KA, Caplan YH, Lodico CP, Bush DM: Urine pH: the effects of time and temperature after collection. J Anal Toxicol 2007;31:486-496.

37 Kwong T, Robinson C, Spencer D, Wiseman OJ, Karet Frankl FE: Accuracy of urine $\mathrm{pH}$ testing in a regional metabolic renal clinic: is the dipstick accurate enough? Urolithiasis 2013;41:129-132.

38 Delanghe J, Speeckaert M: Preanalytical requirements of urinalysis. Biochem Med ( $\mathrm{Za}-$ greb) 2014;24:89-104.

39 Walsh S, Shirley D, Wrong O, Unwin R: Urinary acidification assessed by furosemide and fludrocortisone treatment: an alternative to ammonium chloride. Kidney Int 2007;71: 1310-1316.

40 Wrong O: Distal renal tubular acidosis: the value of urinary $\mathrm{pH}, \mathrm{PCO}_{2}$ and $\mathrm{NH}_{4}^{+}$measurements. Pediatr Nephrol 1991;5:249-255.

41 Galla JH, Kurtz I, Kraut JA, Lipschik GY, Macrae JP: Acid-base disorders; in Lerma E, Berns J, Nissenson A (eds): Current Essentials of Diagnosis \& Treatment in Nephrology \& Hypertension, ed 1. New York, McGraw-Hill Education/Medical, 2012, chapt 5, pp 42-59.

42 Santos F, Ordóñez FA, Claramunt-Taberner D, Gil-Peña H: Clinical and laboratory approaches in the diagnosis of renal tubular acidosis. Pediatr Nephrol 2015;30:2099-2107. 
43 Kim S, Lee JW, Park J, Na KY, Joo KW, Ahn C, Kim S, Lee JS, Kim GH, Kim J, Han JS: The urine-blood PCO gradient as a diagnostic index of $\mathrm{H}^{+}$-ATPase defect distal renal tubular acidosis. Kidney Int 2004;66:761-767.

44 Emmett M: Approach to the patient with a negative anion gap. Am J Kidney Dis 2016;67: 143-150.
45 Danel VC, Saviuc PF, Hardy GA, Lafond JL, Mallaret MP: Bromide intoxication and pseudohyperchloremia. Ann Pharmacother 2001; 35:386-387.

46 Zimmer BW, Marcus RJ, Sawyer K, Harchelroad F: Salicylate intoxication as a cause of pseudohyperchloremia. Am J Kidney Dis 2008;51:346-347.

47 Sousa AG, Cabral JV, El-Feghaly WB, de Sousa LS, Nunes AB: Hyporeninemic hypoaldosteronism and diabetes mellitus: pathophysiology assumptions, clinical aspects and implications for management. World J Diabetes 2016;7:101-111.
48 Haas CS, Pohlenz I, Lindner U, Muck PM, Arand J, Suefke S, Lehnert H: Renal tubular acidosis type IV in hyperkalaemic patients - a fairy tale or reality? Clin Endocrinol (Oxf) 2013;78:706-711.

49 Rastegar A: Use of the $\Delta \mathrm{AG} / \Delta \mathrm{HCO}_{3}{ }^{-}$ratio in the diagnosis of mixed acid-base disorders. J Am Soc Nephrol 2007;18:2429-2431. 